Article

\title{
University-Community Partnerships: A Local Planning Co-Production Study on Calabarzon, Philippines
}

\author{
Lovely S. Mores ${ }^{1}$, Jeongwoo Lee ${ }^{2, *}$ and Woongkyoo Bae ${ }^{3}$ \\ 1 Department of Urban Development and Policy (KOICA-CAU Scholarship Program), Graduate School, \\ Chung-Ang University, 84, Heukseok-ro, Dongjak-gu, Seoul 06974, Korea; lovelymores@gmail.com \\ 2 Department of Urban Design and Studies, Chung-Ang University, 84, Heukseok-ro, Dongjak-gu, \\ Seoul 06974, Korea \\ 3 Campustown Affairs Bureau, Chung-Ang University, 84, Heukseok-ro, Dongjak-gu, Seoul 06974, Korea; \\ baegogh@cau.ac.kr \\ * Correspondence: jeongwoo@cau.ac.kr
}

Received: 8 February 2019; Accepted: 23 March 2019; Published: 27 March 2019

\begin{abstract}
University-community partnerships provide opportunities for collaborations and meaningful engagement with community partners, in order to promote sustainable community development. To date, studies on university-community partnerships have largely neglected partnership potential and readiness prior to partnership formation. These factors enable expectations and targets to be negotiated and potential problems to be anticipated, prior to any formal collaboration. Hence, this study investigates the optimal preconditions-including environment, resources, and motivation - to facilitate successful university-community collaboration for local urban planning. Specifically, a sample of local government units (LGUs) and universities in the Calabarzon region of the Philippines were interviewed and observed to determine their needs and access to planning resources at universities, as well as factors that would ensure sustained partnerships. The results show that there is a need for university-community partnerships in local planning, since LGUs have limited technical capacity in preparing comprehensive land use plans, particularly with respect to data analysis, technical writing, project development, and hazard mapping. Conversely, LGUs have more financial resources than universities. Local universities were determined to be uniquely suited to meet the technical and human resource needs of LGUs. Importantly, though, previous partnership experience was found to dramatically influence both parties' decisions regarding whether or not to pursue a partnership. Accordingly, there is a need to temper the desires and expectations of partner organizations, and lay down the foundations of sustainable university-community partnership prior to partnership formation. Toward this end, policies that bolster partnership institutionalization, funding, and systematic monitoring and evaluation systems can enhance the utility of such partnerships moving forward.
\end{abstract}

Keywords: university-community partnership; local planning; partnership sustainability; local government units; comprehensive land use plans

\section{Introduction}

Town and gown, campus-town, and community engagements are terms used to describe both university-community partnerships [1-3] and more general partnerships that are vital in implementing sustainable community development. The most common partnerships include service learning, local economic development, community-based research, and social work initiatives [2,4-7]. 
Other forms of collaboration include training, technical assistance, program development, and contracted studies [8,9].

In the Philippines, university-community partnerships tend to be of a service-learning type due to a government mandate that public universities provide community outreach and extension programs. Usually, a single university will partner with a community. When there are multi-sectoral stakeholders and required convergence, multiple parties enter into formal contractual arrangements [10]. However, even though contractual agreements often specify the nature of a partnership, delineate roles and responsibilities, and arrange for cost sharing [11], the collaborations often lack depth due to limited contractual foresight, flexibility, and expansion into future collaborations to achieve sustainable and hierarchical outcomes [7].

Recently, universities all over the world have been challenged to step up their community service through two-way engagements, in which they co-create knowledge and co-fabricate products and services [1,12]. As a result, universities are emerging as valuable partners in the sustainable development of nations, regions, cities, and local communities [13-17].

The Carnegie Foundation defines partnership sustainability as "collaboration for the mutually beneficial exchange of knowledge and resources in a context of partnership and reciprocity" [12]. Colding and Barthel [16] and Shiel et al. [18] have added that the role of universities in partnership sustainability is to co-create knowledge and services. Most importantly, Bringle and Hatcher [4] posited that partnerships are most likely to be sustainable when they exceed their target objective, identify other areas for future projects, and develop networks for further collaboration.

Studies on university-community partnerships are much more voluminous in Western countries $[1,3,5,18-23]$ than in Asian countries. This is mostly due to the policies and incentives provided to Western universities to encourage community engagement $[12,20]$. The few studies that are conducted in Asia, such as those on campus town projects in China [23] and Korea [24], are not often published in English. To date, the limited number of university-community partnerships in the Philippines have not been studied [25].

In general, there is a dearth of research on local planning, as most studies focus on social and environmental results from ongoing or completed partnerships [26]. Furthermore, some partnerships have resulted in neglect of local needs due to a lack of in-depth analysis prior to forming a partnership $[14,18,27]$. This study was conducted in the Calabarzon region of the Philippines to investigate university-community partnership potential and necessary preconditions for local planning collaboration before the onset of a partnership.

The Calabarzon region is currently experiencing a backlog in local plan preparation. As of 2017, only $28 \%$ of its local government units (LGUs) have successfully prepared local plans [28]. The region also has a wide range of cities and municipalities; some are highly urbanized and independent, and most are part of a province. In addition to its diverse LGU classifications, there are six state and public universities strategically located within the five provinces (Figure 1).

Unlike China, where limitations in planning linkages and the fear of institutionalized political control [29] limit the efficacy of local planning efforts and partnerships, the quickly developing Philippines is exploring vertical linkages in comprehensive development plans through top-down and bottom-up processes (vertical planning) to ensure harmonious and inclusive socio-economic and physical development. However, vertical planning is difficult to realize in practice, since most LGUs in the Philippines lack approved local plans. Vertical planning and vertical alignment of plans can only be achieved if all government entities, from the national to local level, have approved socioeconomic and physical framework plans. The general lack of approved local plans emanates from LGUs' limited planning capabilities as well as financial and human resources. 


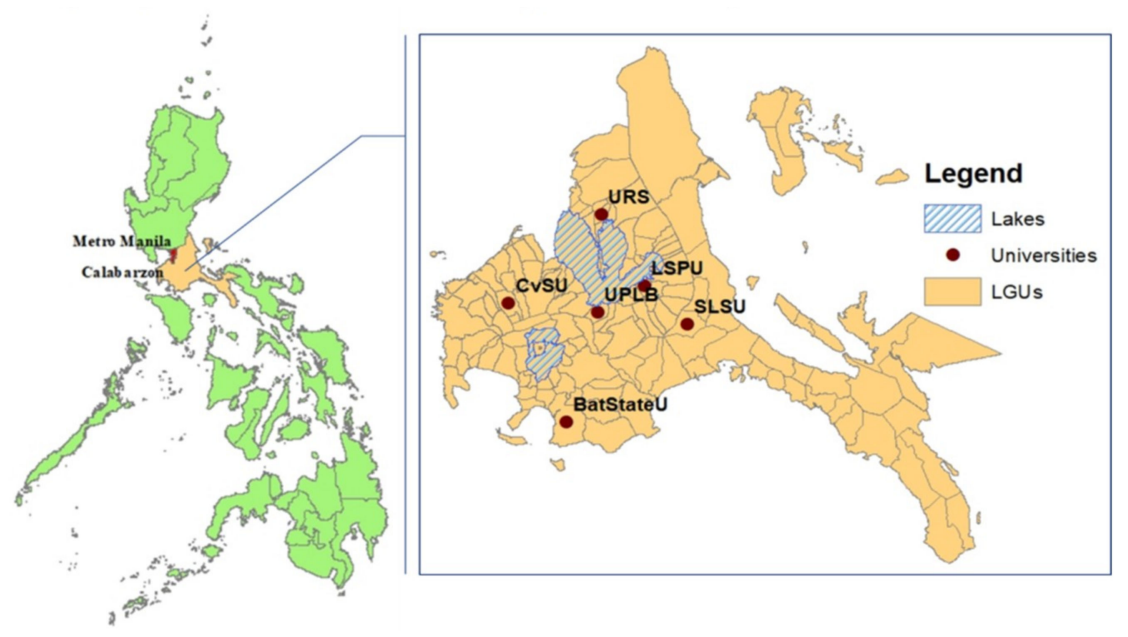

Figure 1. Map of study area.

Most LGUs who do get approved plans hire consultants to prepare them. This is costly and does not empower the LGU to drive sustainable community development [30]. Accordingly, there is a need to seek alternatives to address local planning challenges. One way to do so is to promote university-community partnerships, since this is an existing practice in the Philippines.

In Calabarzon, the University of the Philippines Los Banos has been partnering with several local government units throughout the region and rest of the country [11]. Therefore, local universities have the capability, resources, technology, and strategic location to facilitate local plan preparation at a quicker pace and reduced cost. However, LGUs have yet to take advantage of this resource despite the fact that public universities in the Philippines are growing rapidly with respect to finance, enrolment, and resources [31]. State universities are also mandated to provide extension services, which local plan preparation can be included in.

Universities can access additional funding for programs and projects under the Tier 2 budget allocation for government institutions. Recently, House Bill No. 8370 has dictated that public universities implement land use and infrastructure plans, which has required them to expand their resources and finances in this area [32]. Despite these advantages, Philippine LGUs still hire consultants to prepare their local plans.

Therefore, this study explores the potential of university-community partnerships to produce and enhance local plans for comprehensive urban development. Specifically, we explore the current local planning needs in Calabarzon and how can universities help address them, and elucidate the factors that can hinder, facilitate, and enable sustainable partnerships. Through a mixed methods actual needs assessment of local government units (LGUs) with respect to local planning, this study maps out university capabilities and resources (i.e., financial, technical and human resources) that can be leveraged to address these needs. An additional aim is to assess partnership potential between universities and LGUs, and identify factors that will make partnership sustainable.

Ultimately, this research explores the potential of university-community partnerships to enhance local planning within the context of the Philippines. By addressing the gaps in the aforementioned literature, this study will enhance the literature on Filipino university-community partnerships.

\section{Methods}

A global literature review was conducted to develop a survey based on partnership frameworks and factors identified in previous university-community partnership research (Table 1). In this study, we developed surveys for local government officials and university officials. Purposive sampling was used to target university and LGU officials who had been part of the decision-making process to engage in a partnership. Thus, participants were mostly top officials at LGUs and universities, 
while others, such as planning officers and university faculty members, were directly involved in local planning and community development.

A total of 142 LGUs (cities and municipalities) were considered for this study, and 104 people responded from 77 LGUs ( $54 \%$ response rate). Six state and public universities were considered and 17 responses were gathered from six universities (100\% response rate). The surveys had a combination of multiple-choice questions, checkboxes, an 11-point Likert scale, and open-ended questions.

Six public universities in the Calabarzon region were considered after completion of a pilot study to select local planning and development coordinators as well as university officials. The results of the pilot study revealed that local governments prefer partnerships with public universities, because publicly funded universities in the Philippines are mandated to contribute to the improvement of their communities. The pilot survey was conducted to determine the applicability of the survey questions and incorporate respondents' recommendations into the survey design.

Table 1. Review of the university-community partnership literature.

\begin{tabular}{|c|c|c|c|}
\hline Focus Area & Research Stream & Relevant Indicators & References \\
\hline \multirow{7}{*}{$\begin{array}{l}\text { Needs assessment } \\
\text { and resource } \\
\text { mapping }\end{array}$} & \multirow{7}{*}{$\begin{array}{l}\text { Local and urban } \\
\text { planning }\end{array}$} & $\begin{array}{l}\text { Constraints on technical, financial, } \\
\text { and human resources. }\end{array}$ & Fullerton, 2015 \\
\hline & & $\begin{array}{l}\text { Limited technical capability (e.g., } \\
\text { writing, mapping, data collection, and } \\
\text { analysis). }\end{array}$ & $\begin{array}{l}\text { Dorsey, 2001; Fullerton, } \\
2015\end{array}$ \\
\hline & & Status of local plans. & Fullerton, 2015 \\
\hline & & $\begin{array}{l}\text { University resources (facilities, } \\
\text { hardware, software, and human } \\
\text { resources). }\end{array}$ & $\begin{array}{l}\text { McNall, Brown \& Allen, } \\
2009\end{array}$ \\
\hline & & Human capital and physical & Cox, 2000; Hart \& \\
\hline & & $\begin{array}{l}\text { intrastructure. } \\
\text { Access to facilities and knowledge. }\end{array}$ & Hutchins, 2013; \\
\hline & & Community needs assessment. & Bramwell \& Wolfe, 2008 \\
\hline \multirow{6}{*}{$\begin{array}{l}\text { Assessment of } \\
\text { partnership } \\
\text { potential }\end{array}$} & \multirow{3}{*}{$\begin{array}{l}\text { Local and urban } \\
\text { planning }\end{array}$} & $\begin{array}{l}\text { Scope, target, motivation, key actors, } \\
\text { and role of universities in the } \\
\text { partnership. }\end{array}$ & $\begin{array}{l}\text { Trencher, Yarime, \& } \\
\text { Kharazzi, } 2013\end{array}$ \\
\hline & & Previous partnership experience. & $\begin{array}{l}\text { Weerts and Sandmann, } \\
2010\end{array}$ \\
\hline & & $\begin{array}{l}\text { Partnership benefits (timeliness, cost, } \\
\text { capability building). }\end{array}$ & $\begin{array}{l}\text { McNall, Brown \& Allen, } \\
2009\end{array}$ \\
\hline & \multirow{3}{*}{ Sustainability science } & $\begin{array}{l}\text { Partner location (within or outside the } \\
\text { host-community). }\end{array}$ & Hutchins, 2013 \\
\hline & & Partnership interest. & Hutchins, 2013 \\
\hline & & Partnership strategy. & Hutchins, 2013 \\
\hline \multirow{5}{*}{$\begin{array}{l}\text { Partnership } \\
\text { Sustainability }\end{array}$} & \multirow{3}{*}{ Sustainability science } & Partnership sustainability and issues. & $\begin{array}{l}\text { Hill, Herts, \& Devance, } \\
2014\end{array}$ \\
\hline & & Partnership success factors. & $\begin{array}{c}\text { Mtawa, Fongwa \& } \\
\text { Wangenge-Ouma, } 2015\end{array}$ \\
\hline & & $\begin{array}{l}\text { Partnership-hindering factors } \\
\text { (structures, values, interests). }\end{array}$ & $\begin{array}{l}\text { Hill, Herts, \& Devance, } \\
2014\end{array}$ \\
\hline & \multirow[t]{2}{*}{$\begin{array}{l}\text { Community } \\
\text { engagement }\end{array}$} & $\begin{array}{l}\text { Partnership success factors (goals, } \\
\text { expectations, facilities, monitoring, } \\
\text { and evaluation). }\end{array}$ & \multirow{2}{*}{$\begin{array}{l}\text { Weerts \& Sandman, } 2010 \\
\text { Weerts \& Sandmann, 2010, } \\
\text { Cleveland \& Cleveland, } \\
2018\end{array}$} \\
\hline & & Conflict resolution and reciprocity. & \\
\hline
\end{tabular}


The studies that guided the development of the questionnaire were considered based on their relevance to the research. For instance, Cox [33] and McNall et al. [20] provided insights on understanding common interests and partnership dynamics. From a different perspective, Weerts and Sandmann [12] examined the importance of physical, technical and human resources in university-community partnership formation and sustainability, while Hart and Northmore [34] focused on auditing university-community interactions via public engagement. In addition, Trencher et al. [14] demonstrated that university partnership can dramatically advance sustainable urban transformation.

Hill et al. [17] analyzed issues encountered through partnership phases including problem-setting, direction-setting, and implementation. Recently, Mtawa et al. [19] used Ernest Boyer's framework [35] to investigate the value and contributions of engagement, discovery, teaching, integration, and application of knowledge in determining the success of university-community partnerships. Studies on partnership potential-particularly partnership strategy, location, and interest—were based on the works of Hutchins et al. $[9,13,26]$.

However, these studies largely focused on Western and other developed countries; thus, the partnership experiences and potential in Asia and other regions remain unexplored. Accordingly, these studies were used as evaluative indicators to guide a study design for the Philippines.

This study employs a mixed methods approach to gather quantitative and qualitative data simultaneously, using an online survey (Figure 2). Specifically, quantitative data provides an objective measure of needs and partnership potential, while also addressing differences in partnership perception between LGUs and universities. The qualitative data provides insights into factors that influence partnership decisions, success, and sustainability [36]. The results of the study were combined, and the overall interpretation was drawn from both the qualitative and quantitative stands of the survey.

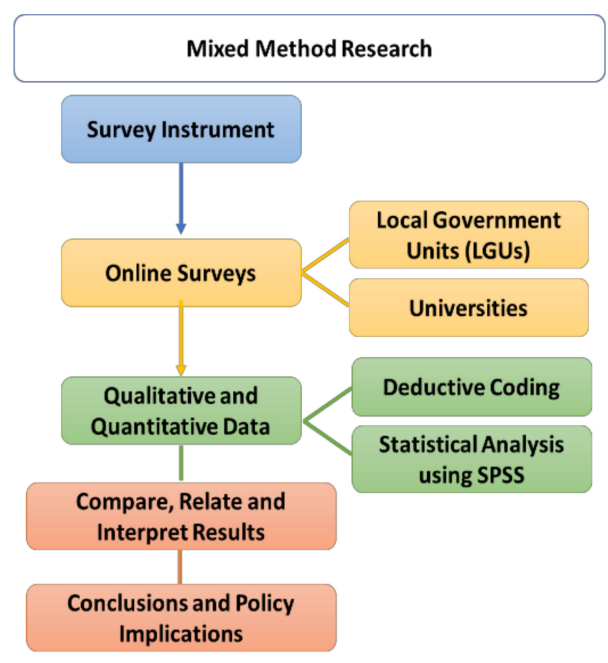

Figure 2. Research process.

Quantitative data gathered from the surveys was analyzed using descriptive statistics and factorial analysis of variance (ANOVA) to identify patterns, trends, and relationships among various indicators, using the Statistical Package for Social Science (SPSS) software. Analysis of qualitative data collected through open questions was performed via deductive coding, in order to elucidate elements that influenced partnership decisions that could not be explained in depth using the quantitative data. 
For deductive coding, data was transcribed from recordings of answers to the open-ended questions. Next, the coded data was grouped into major themes and reviewed to generate sub-themes. Sub-themes were further analyzed to refine the specifics of each theme and then evaluated with respect to the main hypotheses [37,38]. Results were compared and related to each other, then interpreted to derive conclusions and policy implications.

\section{Results and Discussion}

The survey data analysis is divided into four sections. The first covers respondents' demographic information (Table 2); the second assesses partnership potential using variables derived from previous partnership experience, as quantified by a rating of utility, partnership strategies and partner location, as well as interest in the partnership (Table 3); the third deals with needs assessment and resource mapping as well as perceived benefits, including capability matching, to determine if a university-community partnership was necessary; and the last section delineates factors involved in partnership sustainability, based on answers to the open-ended questions (Table 4). Several analytical methods were tested with respect to these explanatory variables, while the qualitative analysis made use of a deductive coding approach to facilitate data analysis.

Table 2. Respondents' demographic and institutional characteristics.

\begin{tabular}{cccc}
\hline \multirow{2}{*}{ Sex of Respondents } & Variables & LGU (\%) & University (\%) \\
& Male & 52 & 71 \\
\multirow{2}{*}{ Years of Employment } & Female & 48 & 29 \\
\hline \multirow{3}{*}{ Position or Designation } & 1 to 10 & 32 & 35 \\
& 10 to 20 & 30 & 24 \\
& 21 or more & 38 & 41 \\
\hline \multirow{2}{*}{ Institution Classification } & Mayor/President & 1 & 11 \\
& Administrator/Dean or Director & 1 & 53 \\
& Planning Officer & 86 & 12 \\
\hline
\end{tabular}

Note: LGU—local government unit.

Table 3. Respondents' preference about partnership.

\begin{tabular}{|c|c|c|c|c|}
\hline \multirow{2}{*}{ Variables (Measurement and Scoring) } & \multicolumn{2}{|c|}{ LGU } & \multicolumn{2}{|c|}{ University } \\
\hline & $\mathbf{M}$ & SD & $\mathbf{M}$ & SD \\
\hline $\begin{array}{l}\text { Previous Partnership } \\
\text { Checkboxes (without previous partnership = } 0 \text {; with previous partnership }=1 \text { ) }\end{array}$ & 0.37 & 0.48 & 0.94 & 0.24 \\
\hline $\begin{array}{l}\text { Previous Partnership Helpfulness } \\
\text { 11-point Likert scale (strongly disagree }=-5 ; \text { strongly agree }=+5 \text { ) }\end{array}$ & 2.12 & 3.98 & 3.41 & 1.33 \\
\hline $\begin{array}{l}\text { Preferred Partnership Strategy } \\
\quad \text { Checkbox }(\text { lead }=1 ; \text { facilitating }=2 ; \text { consulting }=3 ; \text { full }=4)\end{array}$ & 3.11 & 1.00 & 2.71 & 1.05 \\
\hline $\begin{array}{l}\text { Partnership Interest } \\
\text { 11-point Likert scale (not interested at all=-5; extremely interested }=+5 \text { ) }\end{array}$ & 2.77 & 2.05 & 3.59 & 1.50 \\
\hline $\begin{array}{l}\text { Preferred Partner Location } \\
\text { Checkbox (within LGU =1; within province = 2; within region = 3; outside } \\
\text { region }=4 \text { ) }\end{array}$ & 2.68 & 1.08 & 2.76 & 1.25 \\
\hline
\end{tabular}

Note: LGU—local government unit; $\mathrm{M}-$ mean; SD—standard deviation. 
Table 4. Measurement and scoring of variables.

\begin{tabular}{|c|c|c|}
\hline Themes (Assessment) & Variables & Measurement and Scoring \\
\hline \multirow{4}{*}{$\begin{array}{l}\text { Local Planning (needs } \\
\text { assessment and resource } \\
\text { matching) }\end{array}$} & LGU's Local Plan Status & $\begin{array}{c}\text { Checkboxes } \\
(\text { Approved }=1 ; \text { Ongoing Updating }=2 ; \\
\text { Updating }=3 \text { ) }\end{array}$ \\
\hline & LGU Planning Assistance & $\begin{array}{c}\text { Checkboxes } \\
(\text { Self-prepared }=1 ; \text { Assistance }=2 ; \text { Consultants } \\
=3)\end{array}$ \\
\hline & Local Planning Constraints & $\begin{array}{c}\text { Checkboxes } \\
\text { (Data Collection and Analysis = 1; Technical } \\
\text { Writing = 2; Hazard Mapping = 3; Project } \\
\text { Proposal } / \text { Development = 4; Layout and } \\
\text { Editing = 5; Other = 6) }\end{array}$ \\
\hline & Available Planning Resources & 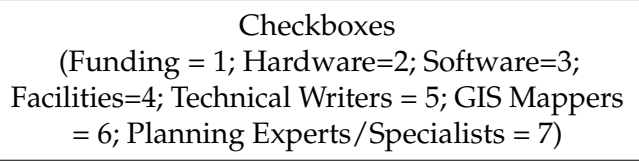 \\
\hline \multirow[t]{3}{*}{$\begin{array}{l}\text { Community Engagement } \\
\text { (partnership potential) }\end{array}$} & $\begin{array}{l}\text { University-Community } \\
\text { Partnership Benefits }\end{array}$ & $\begin{array}{c}\text { Checkboxes } \\
\text { [LGU] } \\
\text { (Timely Plan Preparation = 1; Less Costly than } \\
\text { Hiring Consultants = 2; Access to } \\
\text { Experts } / \text { Specialists = 3; Capability Building } \\
\text { Opportunities for Managers and Staff = 4; } \\
\text { Access to Facilities; Hardware and Software = 5; } \\
\text { Other = 6) } \\
\text { [University] } \\
\text { (Career-oriented Exercises and Skill } \\
\text { Development for Faculty, Staff, and } \\
\text { Students = 1; Positive Community Perception } \\
\text { of University Programs, Projects, and } \\
\text { Activities = 2; Government Funding and } \\
\text { Research Grants = 3; Inclusive Social, Physical } \\
\text { and Economic Development Opportunities = 4; } \\
\text { High Enrollment in Core Courses such as } \\
\text { Agriculture, Engineering, and Other } \\
\text { Science-based Courses = 5; Other = 6) }\end{array}$ \\
\hline & Partnership Success Factors & $\begin{array}{c}\text { Checkboxes } \\
\text { (Common Goals }=1 ; \text { Clear Expectations and } \\
\text { Specific Targets }=2 ; \text { Stakeholder Buy-in }=3 ; \\
\text { Availability of Common Planning Facilities = 4; } \\
\text { Equal Treatment }=5 \text {, Other }=6 \text { ) }\end{array}$ \\
\hline & Partnership-inhibiting Factors & $\begin{array}{c}\text { Checkboxes } \\
\text { (Unequal Power = 1; Competing Interests=2; } \\
\text { Lack of Coordination and Communication = } \\
\text { Different Organizational Values =4; Different } \\
\text { Timelines = 5; Loss of Autonomy = 6; Resource } \\
\text { Drain = 7; Implementation Challenges = 8; } \\
\text { Physical Distance = 9; Ambivalence due to } \\
\text { Prior Partnership Experience }=10 \text {, Other }=11 \text { ) }\end{array}$ \\
\hline Partnership Sustainability & $\begin{array}{c}\text { Conflict Resolution } \\
\text { Partnership Reciprocity } \\
\text { Partnership Sustainability }\end{array}$ & $\begin{array}{l}\text { Open-ended Questions } \\
\text { Open-ended Questions } \\
\text { Open-ended Questions }\end{array}$ \\
\hline
\end{tabular}

\subsection{Assessment of Needs, Resources, and Partnership Potential}

A comparative analysis was conducted to assess LGUs' needs, resources, and capabilities. Results showed that a majority of LGUs in the region either needed to update their comprehensive land use plan (CLUP) or were still undergoing the planning process. Only $42 \%$ had approved CLUPs at the time of the study; thus, there is a need to ensure that all LGUs in the region will be able to prepare 
their mandated local plans. Further, nearly $44 \%$ received assistance from other government agencies, while $39 \%$, hired consultants to prepare their land use plans. Only $17 \%$ were able to autonomously prepare the plans.

In order to understand this phenomenon, constraints faced by the LGUs were assessed. More than $50 \%$ experienced limitations in technical resources for data collection and analysis, technical writing, hazard mapping, and layout and editing (Figure 3a). These are major setbacks, as local planning is primarily a technical process. Thus, universities' planning capabilities were compared with those of LGUs.

The survey data indicates that universities are more technically equipped in all planning aspects, except layout and editing. However, only $50 \%$ of university respondents indicated that they were capable of addressing local planning constraints such as data collection, technical writing, and hazard mapping, among others. Hence, there is a need to enhance universities' capabilities and skills in local planning to ensure that they are able to share knowledge and technology to realize comprehensive plans for sustainable community development.

In terms of resources, LGUs were shown to have more funding, hardware, software, and facilities; whereas, universities had technical writers, GIS mappers, and planning experts (Figure 3b). This indicates that LGUs have more physical and financial resources, while universities have the necessary human resources and expertise.

Finally, preferred partnership strategies and locations were considered. Figure $3 \mathrm{c}$ shows that most LGUs preferred full-partnerships, while most universities preferred facilitating partnerships or full-partnerships. Full-partnership involves co-creation of a local plan, from data collection to technical writing, and finally to publication. A facilitating partnership delineates the role of a university as a facilitator of plan preparation, while the bulk of planning tasks remain under the purview of LGUs.

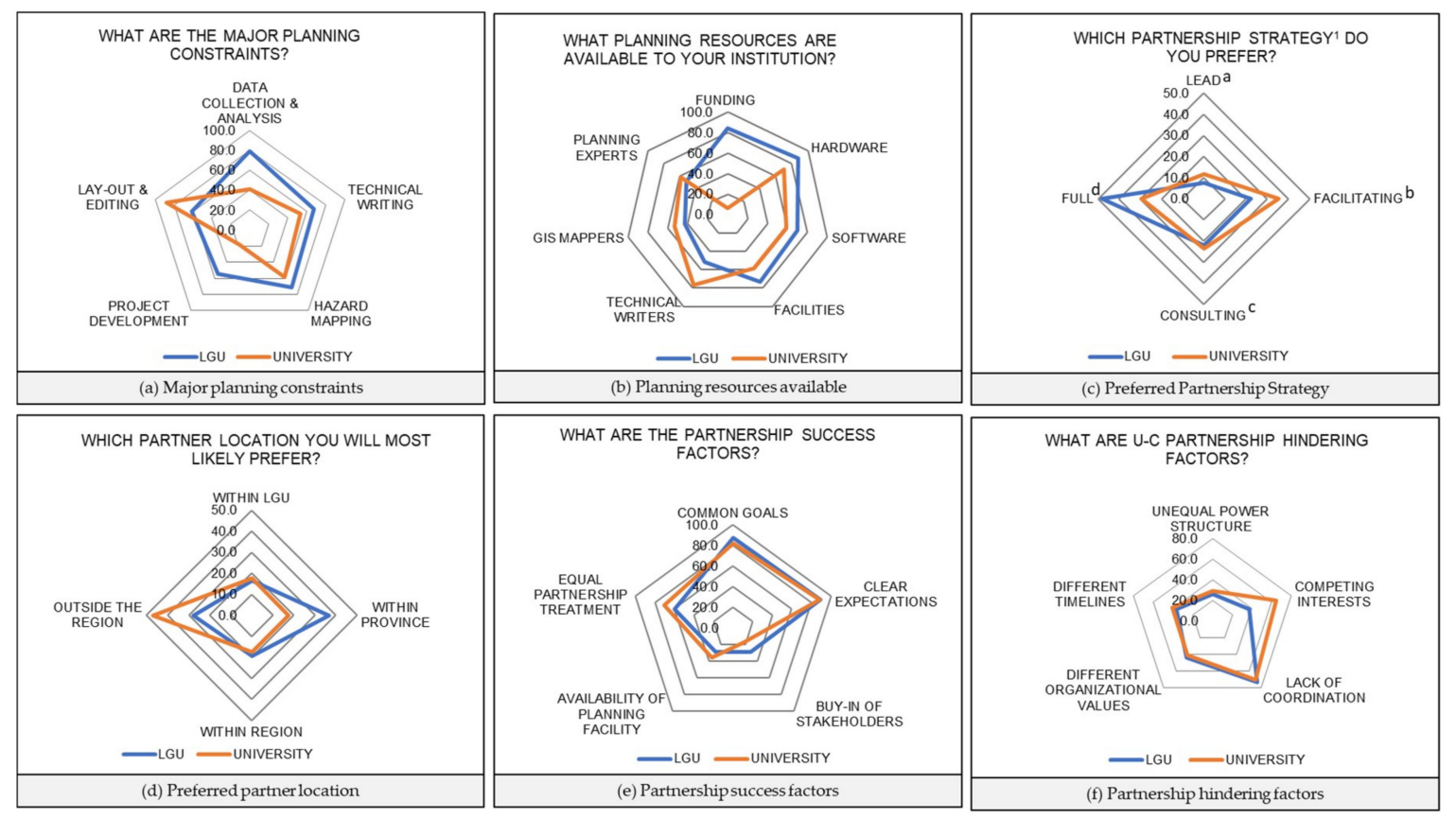

Figure 3. Differences in partnership potential factors indicated by LGUs and universities. Partnership strategy is categorized into (a) lead (universities lead only in problem identification, up to a proposed solution), (b) facilitating (university facilitates the plan preparation), (c) consulting (university is consulted on all aspects of planning, and may take part in the actual plan preparation), and (d) full (partners work together in all stages of the planning process).

We invited participants to describe how helpful previous partnerships had been for local planning. Statistically significant results were found for both partnership utility and importance (Table 5; Table 6), and therefore served as crucial indicators of an LGU's amenability to forming university partnerships 
for comprehensive land use plans. We also asked respondents to report how important a partnership was perceived to be in addressing local planning challenges.

Table 5. Univariate general linear model for assessing previous partnership utility ( $\mathrm{n}=121)$.

\begin{tabular}{cccc}
\hline \multirow{2}{*}{ Variable } & \multicolumn{3}{c}{ Previous Partnership Utility } \\
& B & $t$ & Sig. \\
\hline Sex (male $=$ 0, female $=1)$ & 0.275 & 0.666 & 0.507 \\
Previous Partnership & 6.552 & 14.945 & $0.000^{* * *}$ \\
Years of Employment $(\leq 10)$ & Reference & & \\
Years of Employment $(11-20)$ & -1.005 & -1.936 & $0.055^{*}$ \\
Years of Employment (21 or more) & -1.094 & -2.271 & $0.025^{* *}$ \\
Organization (LGU) & Reference & & \\
Organization (university) & 1.669 & 2.712 & $0.008^{* * *}$ \\
\hline & \multicolumn{2}{c}{$R^{2}=0.73$ (Adjusted $R^{2}=0.72$ ) } \\
Note: $\mathrm{n}=$ total sample size; B = coefficient; $t=t$-value; Sig. = significance; ${ }^{* * *}$ significant at $0.001 ;{ }^{* *}$ significant at \\
$0.05 ;{ }^{*}$ significant at 0.1.
\end{tabular}

Table 6. Univariate general linear model for assessing partnership importance $(n=121)$.

\begin{tabular}{cccc}
\hline Variable & \multicolumn{3}{c}{ Partnership Importance } \\
& B & $t$ & Sig. \\
\hline Sex (male = 0, female $=1)$ & -0.714 & -2.104 & $0.038^{* *}$ \\
Previous Partnership & 0.766 & 2.044 & $0.043^{* *}$ \\
Years of Employment ( $\leq 10)$ & Reference & & \\
Years of Employment (11-20) & 0.488 & 1.134 & 0.259 \\
Years of Employment (21 or more) & -0.009 & -0.022 & 0.983 \\
Organization (LGU) & Reference & & \\
Organization (university) & 1.281 & 2.533 & $0.013^{* *}$ \\
Partnership strategy (full) & Reference & & \\
Partnership strategy (lead) & -1.603 & -2.528 & $0.013^{* *}$ \\
Partnership strategy (facilitating) & -1.181 & -2.848 & $0.005^{* * *}$ \\
Partnership strategy (consulting) & -0.736 & -1.688 & $0.094 *$ \\
Partner Location (anywhere) & Reference & & \\
Partner Location (within LGU) & -1.003 & -1.931 & $0.056^{*}$ \\
Partner Location (within province) & -0.336 & -0.764 & 0.446 \\
Partner Location (within region) & 0.276 & 0.607 & 0.545 \\
\hline & \multicolumn{2}{c}{$R^{2}=0.26$ (Adjusted $R^{2}=0.18$ ) } \\
\hline
\end{tabular}

Note: $\mathrm{n}=$ total sample size; $\mathrm{B}=$ coefficient, $t=t$-value; Sig. = significance; ${ }^{* * *}$ significant at $0.001 ;{ }^{* *}$ significant at $0.05 ;$ * significant at 0.1 .

Since there is clearly potential synergy based on the needs, resources, and other partnership factors considered, an in-depth analysis of partnership potential was carried out using an univariate general linear model in which the main effects of different variables were assessed against two dependent variables_previous partnership utility and partnership importance-using an 11-point Likert-scale.

The decision to form a partnership can be influenced by previous partnership experience and the organization to which the respondent belonged to. Respondents without prior experience viewed partnership as unhelpful, while those with prior experience perceived it as helpful. Collectively, $63.5 \%$ of LGU respondents indicated that they did not have prior experience in partnering with universities, while a $94.1 \%$ of university respondents had experience engaging with LGUs. Interestingly, a majority of respondents with fewer than ten years of employment history perceived previous partnerships as helpful, while those with more years of employment perceived them as unhelpful.

These results are particularly important because previous partnership utility seemed to create different perceptions of the importance of university-community partnership. When potential partners believed that they had benefitted from previous partnerships, they were more amenable 
to future partnerships, and vice versa. Thus, from these results we can conclude that previous partnerships, years of employment, and organization type significantly influenced the respondents' perception of previous partnership utility. Accordingly, there is a need to reconcile the preconceptions and expectations of universities and LGUs to ensure that partnerships will be mutually beneficial and sustainable.

Furthermore, male respondents from LGUs rated partnership importance higher than their female counterparts, while the opposite was true for university respondents. Regardless, both LGU and university respondents preferred a full-partnership strategy, in which both organizations could work together throughout all planning stages. Alternatively, all respondents preferred a facilitating partnership over a consulting or lead partnership strategy. This can be attributed to the fact that local planning in the Philippines remains under the purview of LGUs, which are very responsive to technical assistance from outside organizations.

Unsurprisingly, respondents with prior partnership experience indicated that partnerships had been important in addressing local planning challenges, while those without prior partnership engagement were unsure of its importance. At the organizational level, LGU respondents rated partnership importance lower than those from universities. In terms of preferred partner location, universities in the Philippines are strategically located in provinces and regions, making them geographically convenient for such collaborations.

While sex, previous partnership, preferred partnership strategy, and organization significantly affected respondents' perceptions of university-community partnership importance, years of employment did not. In addition, perceived partnership benefits impacted such opinions. LGU respondents recognized that partnerships would be less costly than hiring consultants. They also perceived that partnerships would enable more access to planning experts and capacity-building resources.

Meanwhile, university respondents indicated that partnerships would contribute to inclusive social, physical, and economic development for both the university and LGU. Respondents also recognized that the partnership would generate positive community perceptions of the programs, projects, and activities of the university. These results are important, since the formation of a partnership mainly depends on whether or not both parties would benefit from the partnership.

\subsection{Sustainability Factors for University-Community Partnerships}

Once a partnership is established, it needs to be sustainable. Here, deductive coding was used to identify major themes and sub-themes from open-ended survey questions to delineate logistical and subjective factors that may contribute to the success of these partnerships. Respondents were asked how partners could resolve conflicts that might arise during planning. Common indicators were grouped into three categories: (1) People-assigning explicit roles and determining values needed to resolve conflicts; (2) Partnership Management-factors that ensure proper management and conflict resolution; and (3) Solution Generation - pathways to and factors involved in solution brainstorming (Figure 4).

Moreover, respondents indicated that clear-cut and well-defined roles and responsibilities were essential to avoid conflicts. Additionally, key synergistic values included commitment, transparency, respect, openness, and flexibility. In this regard, good communication and coordination including regular meeting and feedback as well as use of technology and social media were identified as crucial for fast and timely coordination.

Institutionalization was very important in avoiding and resolving conflicts. This includes getting support from top-management-for instance, the Local Chief Executive for LGUs and the President and Board of Directors for universities. To fully institutionalize partnerships, there is a need for a written memorandum of understanding or memorandum of agreement, ordinances, or terms of reference. There is also a need to mediate between interests, timelines, and targets. Ultimately, mutual understanding is crucial in conflict prevention and resolution. 


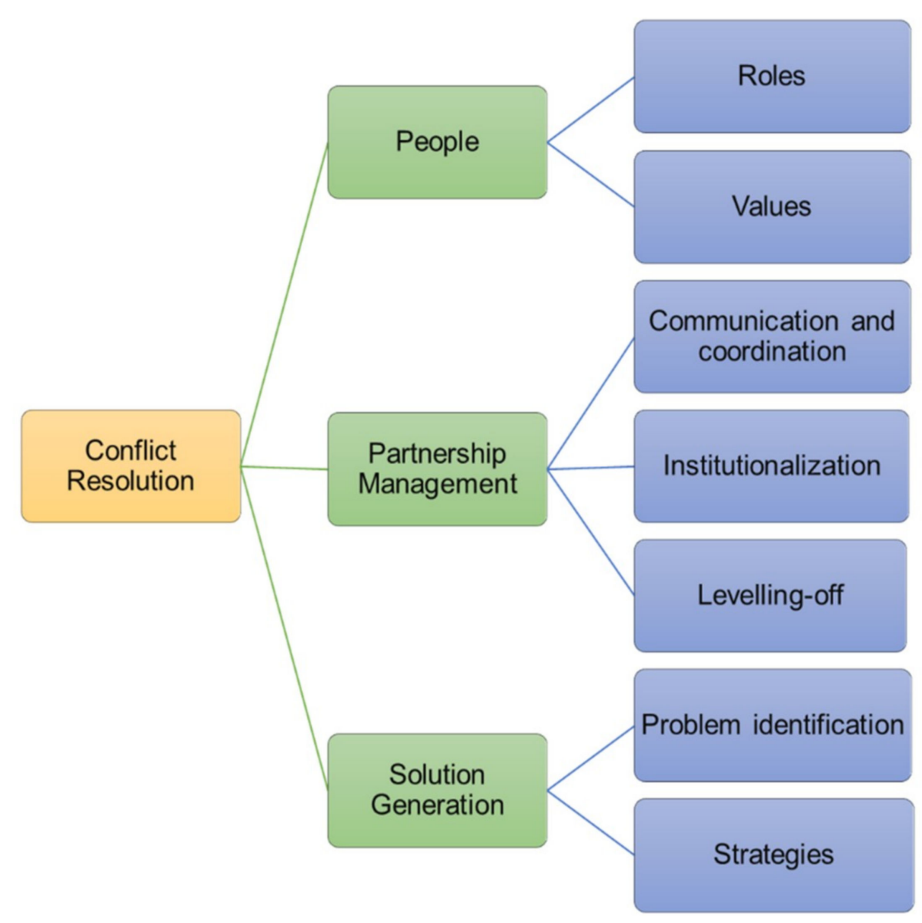

Figure 4. Conflict resolution factors.

Toward this end, conflict resolution needs solutions. Respondents indicated that when conflicts could not be avoided, or had already happened, there was a need to identify and discuss the problem. This enabled both parties to brainstorm resolution strategies and learn from mistakes to prevent them in the future. Figure 5 presents the importance of reciprocity, in the form of actions and incentives, to successful and sustainable partnerships.

To ensure reciprocal partnerships, both the LGU and university need a proper structure, personnel, and mutually reinforcing upon core values. Specifically, a high level of reciprocity could be maintained if there were clear contractual documents and consistent, uninterrupted staff participation. Since the timelines of LGUs and universities are different, there is an unusually high turnover rate for project implementers, which most believed was detrimental to maintaining reciprocity.

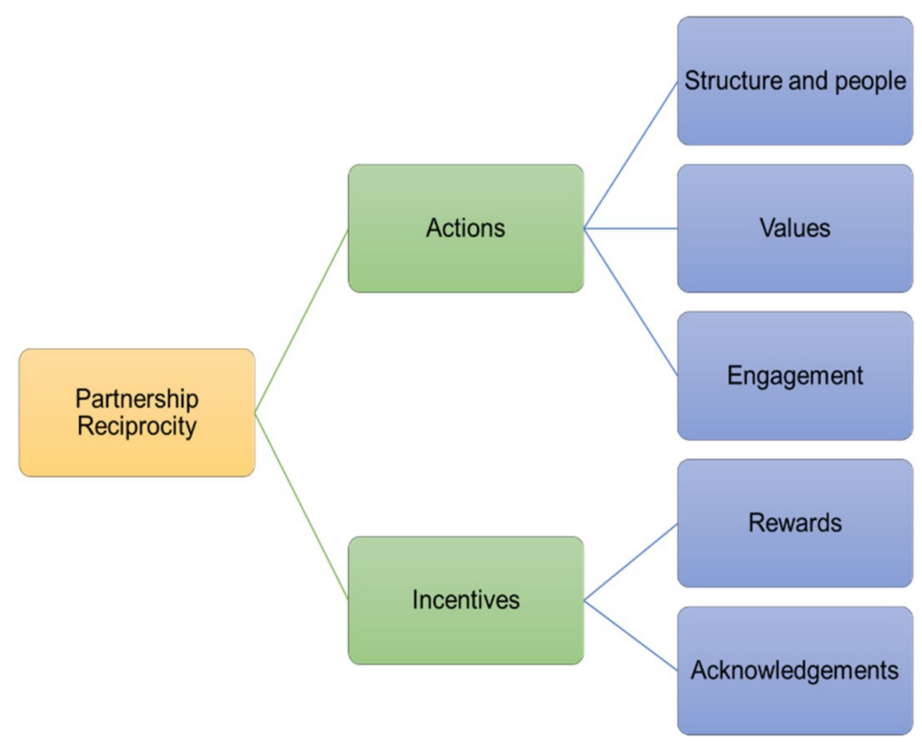

Figure 5. Partnership reciprocity factors. 
One respondent even mentioned that "truthfulness of helping should be there and hopefully, universities would consider LGU as an area to develop instead of a mere study area for university students." This response referenced a prior university-community partnership experience where university faculty and students went out to the community for research and stopped the engagement once the study had finished.

This is not a unique situation localized to the Philippines. Some universities in other parts of the world also reported being open to one-sided community engagement, in which faculty and students would improve the community in a unilateral fashion [1]. Likewise, Shiel et al., suggested that more university-community engagements focus on providing faculty and students with experiences in the community and less on equal and long-term partnerships [18]. In this regard, continuous two-way engagement and networking for further projects seemed to be important to establishing a sense of trust.

Incentives were also needed to encourage participation and trust. These included sharing of resources, establishing small wins, learning from each other, not treating each other as competitors, and appealing to mutualism. Such reciprocity helps ensure successful, sustainable partnerships [19].

In general, factors influencing reciprocity were parsed into pre-partnership, partnership, and post-partnership categories (Figure 6). Pre-partnership factors included processes, structures, and institutionalization mechanisms. Respondents emphasized a need for a written agreement to clearly define the roles and responsibilities of both parties. Structures must also be in place before the partnerships begin to ensure that there is a balance of power and equality.

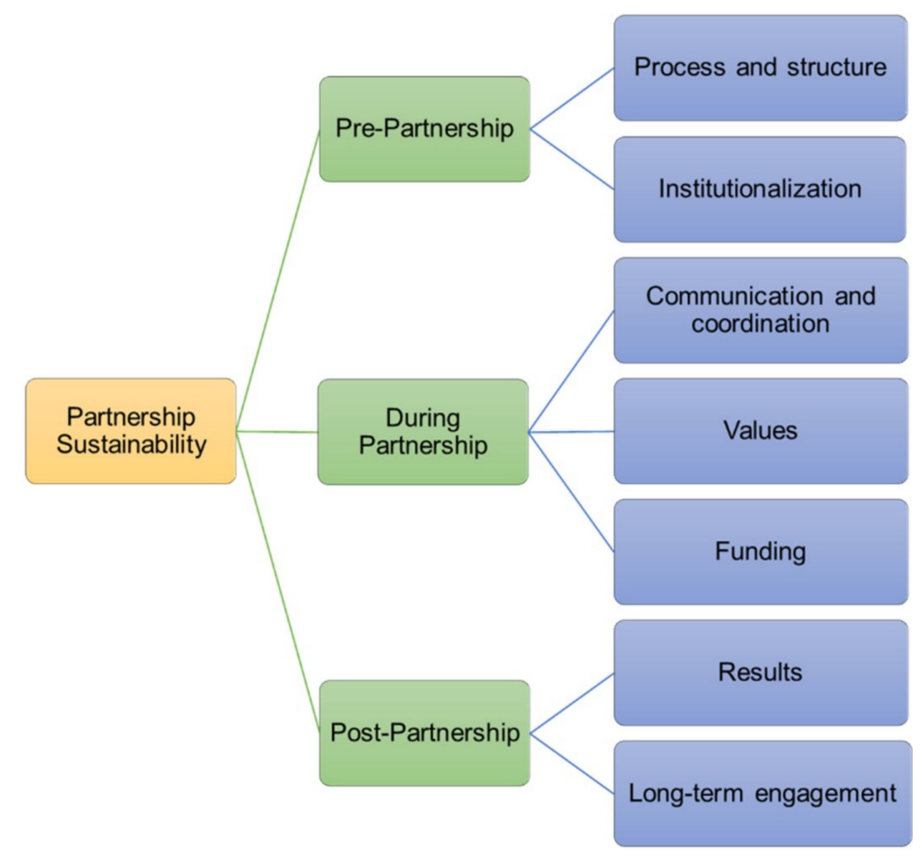

Figure 6. Partnership sustainability factors.

Critically, respondents recognized a need for a memorandum or ordinance that would institutionalize the partnership. Unsurprisingly, these factors are the same as those mentioned as being important for conflict resolution and partnership reciprocity, with the addition of political will, since LGUs are political bodies whose decision-making is highly influenced by the local Chief Executive. This reinforces that the organization and institutionalization of the project could ensure university-community partnership sustainability.

While a partnership was active, respondents highlighted the importance of communication and coordination, including proper documentation of the partnership milestones and other accomplishments. Respondents also mentioned that partnership sustainability could be achieved through the transparency, accountability, and integrity of both parties, at all times. Here, sufficient annual funding was equally important. This could be achieved through the inclusion 
of partnership allocation in the maintenance and other operating expenses and inclusion in local development investment programs.

After the partnership, sustainability could be ensured if it was mutually beneficial, had measurable effects, could be replicated, promoted inclusive growth, and produced the desired outputs. Often, long-term engagements for which there was continuity of partnership and networking as well as lifelong learning were both empowering and successful, because partners were able to learn skills from each other and build trust. Further, there was a need for the development and use of new ideas, methods, and products to promote the creative implementation of integrated and sustainable planning activities. The results of this study indicate the importance of reporting, monitoring, and evaluation, as well as the role played by top officials and local councils to assure quality, transparency, and accountability [15,39].

Comparatively, partnership reciprocity differs from partnership sustainability in that partnership reciprocity covers the factors by which partners interact in a reciprocal and mutually beneficial manner. Partnership sustainability deals with factors that will deepen community engagement that supports partnership reciprocity and eventually enables sustainable partnership, and even after the partnership has ended.

The results of this study also adhere to the principles of good community-campus partnership detailed by Wilson et al. [40], who specified the necessity of trust and commitment to sort out differences and biases. These authors also recognized the importance of a memorandum of agreement and other contractual agreements to ensure accountability. Other factors included issues of power structures and funding, as well as communication and internal politics. While previous studies $[39,40]$ support the results of the study, their study was conducted after the formation of the partnership; hence, the results became part of holistic recommendations for future studies. Conversely, we have tried to elucidate potential sustainability indicators and factors in all stages of partnership implementation.

Although each partnership had different scopes, targets, motivations, and roles, most participants valued institutionalization, communication, coordination, common goals and objectives, and creativity and innovation. Moreover, these partnerships promoted community engagement and advancement led by a university, thereby enabling it to fulfill its role as a driver of community success.

\section{Conclusions and Policy Implications}

The results presented here clearly indicate that a majority of LGUs still need assistance in preparing local plans, particularly land use plans, as indicated by the limited number of LGUs with approved CLUPs, especially those that are completed autonomously. LGUs are limited with regard to technical preparation of plans, data collection and analysis, technical writing, and hazard mapping. Fortunately, universities have the necessary technical capacity and resources to address these local planning challenges. The synergy between local government needs and university resources indicates that there is potential in university-community partnerships to address local urban planning challenges.

While studies like the one conducted by Fullerton [22] reported similar results in terms of local planning challenges and resources available to the community, this study provides a broader range of perspectives from LGUs with diverse classifications and geographic locations. This suggests that university-community partnership for local planning is both viable and beneficial, regardless of a municipality-specific logistics and geographic location; its potential just needs to be tapped to realize sustainable and inclusive local development.

Importantly, this study shows that the decision to pursue a university-community partnership can be influenced by an employee's organization—LGU or university—and other variables such as strategic agreement, previous partnerships, and potential benefits. The success and sustainability of these projects are largely determined by mutual benefit, support from top management via policy or regulation, and good monitoring and evaluation systems, not only during implementation but also after the partnership has ended. Monitoring and evaluation systems can help ensure better implementation 
of partnership programs in the long run. In this regard, communication and organizational values cannot be discounted if the goal is to ensure partnership sustainability.

The policy implications and recommendations of this study are grouped into four categories: organizational, meaning policies, and recommendations to improve organization-level challenges; institutional arrangements implemented at the national level; political motions, which include management concerns and political implications; and sustainability, pertaining to policies and recommendations that will contribute to successful, long-term maintenance of a partnership.

Organizations should conduct in-depth assessments of local planning needs, rather than accepting an overview of local challenges. There is also a need to look closely at the roles of decision-makers and top officials, as well as those of regular staff members directly involved in local planning and community engagement. Attention should also be given to ensure that universities enhance their capacity to provide services for communities, and that LGUs are open to further collaboration with universities to achieve inclusive growth in the future. Addressing organizational challenges is not unique in the Philippines, as it was extensively discussed in the studies conducted by Daneri et al [5] and Shiel et al. [18] however, this study contributes to the literature by providing additional empirical evidence on the importance of organizational capability and stakeholders buy-in when it comes to partnership formation.

Moving up in scale, the Commission on Higher Education of the Philippines must encourage universities to deepen their commitment to achieving meaningful community engagement. This can be attained by institutionalizing community engagement via its inclusion in the core values, mission, and vision of the university, and through policies from the regional and national governments. LGUs can also push for institutionalization of this kind by creating and adopting laws and ordinances that will foster cooperation between a local government and universities. Institutionalization was also discussed by Mtawa et al. [19]; however, the scope of proposed institutionalization pertained to the interplay of community engagement in teaching and research. The institutionalization proposed in this study is holistic in a sense that it covers the issuance of policy and other institutional mechanisms at the national level to promote and deepen community engagements, not only in local planning but also throughout the entire development process.

To ensure partnership sustainability, the engagement must also transcend political boundaries, and conflicting interests must be resolved by looking at the goals of each entity as a unified objective. There is also a need to ensure transparency, accountability, and integrity in all aspects of a partnership. Furthermore, partnership sustainability can be achieved through trust and confidence, and can lead to other partnership opportunities.

Lastly, the new knowledge that a monitoring and evaluation system can provide could help in improving community engagement in the future. Some literatures on university-community partnership in sustainability science proved to be extensive, however it seldom demonstrates the importance of monitoring and evaluation in partnership sustainability [26].

The contribution of this study lies in its focus on examining the potential of university-community partnerships in local urban planning. It also highlights factors that can be considered to ensure partnership sustainability before, during, and after the partnership. The research differs from most of the studies on university-community partnership because it does not focus on auditing and evaluating partnerships; rather, emphasis is placed on providing a framework for implementing university-community partnerships throughout various stages of partnership development. However, since this study focused only on one region of the Philippines, it is premature to generalize the results to the whole country or other countries. This study also limited its data collection to top officials and decision-makers, which indicates that it lacks comprehensiveness in terms of considering all stakeholders.

Moreover, while local planning is an important aspect in socio-economic development, university-community partnerships do not end with planning exercises alone. Universities are taking on a bigger role in partnering with local communities throughout the planning process, from planning 
exercises and their implementation to monitoring and evaluation, and then planning again for the next cycle. Hence, future researchers can conduct studies that are more comprehensive in terms of scope (study area, participants, and topic) and consider partnership potential not only for local planning, but also throughout the whole planning cycle.

Author Contributions: Conceptualization has been done by all authors; methodology, L.M. and J.L.; formal analysis, L.M. and J.L.; investigation, L.M.; resources, L.M.; data curation, L.M.; writing-original draft preparation, L.M. and J.L.; writing-review and editing, L.M. and J.L.; supervision, J.L. and W.B.; funding acquisition, J.L.

Funding: This research was supported by the Chung-Ang University Research Grants in 2018.

Conflicts of Interest: The authors declare no conflict of interest.

\section{References}

1. Bruning, S.; McGrew, S.; Cooper, M. Town-gown relationships: Exploring university-community engagement from the perspective of community members. Public Relat. Rev. 2006, 32, 125-130. [CrossRef]

2. Fisher, R.; Fabricant, M.; Simmons, L. Understanding contemporary university-community connections: Context, practice, and challenges. J. Community Pract. 2004, 12, 13-34. [CrossRef]

3. Cooper, J.; Kotval-K, Z.; Kotval, Z.; Mullin, J. University community partnerships. Humanities 2014, 3, 88-101. [CrossRef]

4. Bringle, R.; Hatcher, J. Campus-community partnerships: The terms of engagement. J. Soc. Issues 2002, 58, 503-516. [CrossRef]

5. Daneri, D.R.; Trencher, G.; Petersen, J. Students as change agents in a town-wide sustainability transformation: The Oberlin Project at Oberlin College. Curr. Opin. Environ. Sustain. 2015, 16, 14-21. [CrossRef]

6. Mayfield, L.; Hellwig, M.; Banks, B. The Chicago response to urban problems: Building university-community collaborations. Am. Behav. Sci. 1999, 42, 863-875. [CrossRef]

7. Howitt, R. Governance in local government-university partnerships: Smart, local and connected. SOAC 2013, 1,11 .

8. Laninga, T.; Austin, G.; McClure, W. Community-university partnerships in small-town Idaho: Addresing diverse community needs through interdisciplinary outreach and engagement. J. Community Engagem. Scholarsh. 2011, 4, 5 .

9. Hutchins, K.; Conrad, E. Building statewide community-University partnerships: Working with the Maine Municipal Association. Maine Policy Rev. 2012, 21, 40-45.

10. CHED. In Commision on Higher Education Memorandum Order No. 52; Commission on Higher Education: Quezon City, Philippines, 2016. Available online: https://ched.gov.ph/wp-content/uploads/2017/10/ CMO-52-s.-2016.pdf (accessed on 27 March 2019).

11. UPLB-DCERP. Department of Community and Environmental Resource Planning; University of the Philippines Los Banos: Los Banos, Philippines, 2018.

12. Weerts, D.J.; Sandmann, L.R. Community engagement and boundary-spanning roles at research universities. J. High. Educ. 2010, 81, 632-657. [CrossRef]

13. Hutchins, K.; Lindenfeld, L.; Bell, K.; Leahy, J.; Silka, L. Strengthening knowledge co-production capacity: Examining interest in community-university partnerships. Sustainability 2013, 5, 3744-3770. [CrossRef]

14. Trencher, G.P.; Yarime, M.; Kharrazi, A. Co-creating sustainability: Cross-sector university collaborations for driving sustainable urban transformations. J. Clean. Prod. 2013, 50, 40-55. [CrossRef]

15. Cleveland, M.; Cleveland, S. Building engaged communities-A collaborative leadership approach. Smart Cities 2018, 1, 155-162. [CrossRef]

16. Colding, J.; Barthel, S. The role of University campuses in reconnecting humans to the biosphere. Sustainability 2017, 9, 2349. [CrossRef]

17. Hill, D.; Herts, R.; Devance, R. The Newark Fairmount Promise Neighborhood: A Collaborative University-Community Partnership Model. Metrop. Univ. 2014, 25, 127-153.

18. Shiel, C.; Leal-Filho, W.; Do Paco, A.; Brandli, L. Evaluating the engagement of universities in capacity building for sustainable development in local communities. Evaluation Program Plan. 2016, 54, 123-134. [CrossRef] [PubMed] 
19. Mtawa, N.; Fongwa, S.; Wangenge-Ouma, G. The scholarship of university-community engagement: Interrogating Boyer's model. Int. J. Educ. Dev. 2016, 49, 126-133. [CrossRef]

20. McNall, M.; Reed, C.; Brown, R.; Allen, A. Brokering community-university engagement. Innov. High. Educ. 2009, 33, 317-331. [CrossRef]

21. Dorsey, B. Linking theories of service-learning and undergraduate geography education. J. Geogr. 2001, 100, 124-132. [CrossRef]

22. Fullerton, C.A. University-community partnerships as a pathway to rural development: Benefits of an Ontario land use planning project. J. Rural Community Dev. 2015, 10, 56-71.

23. Ruoppila, S.; Zhao, F. The role of universities in developing China's university towns: The case of Songjiang university town in Shanghai. Cities 2017, 69, 56-63. [CrossRef]

24. Chu, H.S.; Baek, T.Y.; Kang, J.M. Review of the Physical Evaluation Factors of the Campustown Project-Focused on Seoul Campustown Project. J. Korean Soc. Civ. Eng. 2018, 38, 149-157.

25. Medina, M.A. A Community Extension Framework for Philippine Higher Education Institutions: A Model Developed from Small-Scale Climate Change Adaptation Projects of Central Mindanao University. World Sci. News 2018, 105, 204-211.

26. Hutchins, K.K. Strengthening the Development of Community-University Partnerships in Sustainability Science Research; The University of Maine: Orono, ME, USA, 2013.

27. Bunnell, G.; Lawson, C. A public university as city planner and developer: Experience in the "capital of gfood planning". Plan. Pract. Res. 2006, 21, 25-43. [CrossRef]

28. RDP. Calabarzon Regional Development Plan 2017-2022; National Economic and Development Authority Region IV-A: Calamba City, Philippines, 2017.

29. Leaf, M.; Hou, L. The "third spring" of urban planning in China: The resurrection of professional planning in the post-Mao era. China Inf. 2006, 20, 553-585. [CrossRef]

30. DILG. Rationalized Planning System in the Philippines; Department of the Interior and Local Government: Quezon City, Philippines, 2008.

31. CHED. Higher Education Statistical Data. Available online: https://ched.gov.ph/statistics/ (accessed on 3 March 2019).

32. Torregoza, H. SUCs Soon to be Required to Implement Land Use Development, Infrastructure Plan. Manila Bulletin, 25 February 2019.

33. Cox, D. Developing a framework for understanding university-community partnerships. Cityscape 2000, 5, 9-26.

34. Hart, A.; Northmore, S. Auditing and evaluating university-community engagement: Lessons from a UK case study. High. Educ. Q. 2011, 65, 34-58. [CrossRef]

35. Boyer, E. Scholarship Reconsidered: Priorities of the Professoriate; Princeton University Press: Lawrenceville, NJ, USA, 1990.

36. Creswell, J.W. A Concise Introduction to Mixed Methods Research; Sage Publications: Thousand Oaks, CA, USA, 2014.

37. Braun, V.; Clarke, V. Using thematic analysis in psychology. Qual. Res. Psychol. 2006, 3, 77-101. [CrossRef]

38. Stuckey, H. The second step in data analysis: Coding qualitative research data. J. Soc. Health Diabetes 2015, 3, 7. [CrossRef]

39. Bilau, A.; Witt, E.; Lill, I. Practice Framework for the Management of Post-Disaster Housing Reconstruction Programmes. Sustainability 2018, 10, 3929. [CrossRef]

40. Wilson, S.; Campbell, D.; Dalemarre, L.; Fraser-Rahim, H.; Williams, E. A critical review of an authentic and transformative environmental justice and health community-University partnership. Int. J. Environ. Res. 2014, 11, 12817-12834. [CrossRef] [PubMed]

(C) 2019 by the authors. Licensee MDPI, Basel, Switzerland. This article is an open access article distributed under the terms and conditions of the Creative Commons Attribution (CC BY) license (http:/ / creativecommons.org/licenses/by/4.0/). 